\title{
INSIGHT IN THE CURRENT PROGRESS IN THE LARGEST CLINICAL TRIALS FOR COVID-19 DRUG MANAGEMENT (AS OF JANUARY 2021)
}

\author{
Irina Panovska-Stavridis ${ }^{1}$, Nevenka Ridova ${ }^{1}$, Tatjana Stojanoska ${ }^{2}$, Ilir Demiri ${ }^{2}$, \\ Milena Stevanovic ${ }^{2}$, Simona Stojanovska ${ }^{1}$, Tara Ristevska ${ }^{1}$, Aleksandar Dimkovski ${ }^{3}$, \\ Venko Filipce ${ }^{4}$, Aleksandar Dimovski ${ }^{3,5}$, Aleksandra Grozdanova ${ }^{3}$ \\ ${ }^{1}$ University Clinic of Hematology, Medical Faculty, University Ss. Cyril and Methodius, Skopje, Republic of North Macedonia \\ ${ }^{2}$ University Clinic of Infection Diseases and Febrile Conditions, Faculty of Medicine, University Ss. Cyril and Methodius, \\ Skopje, Republic of North Macedonia \\ ${ }^{3}$ Faculty of Pharmacy, University Ss. Cyril and Methodius, Skopje, Republic of North Macedonia \\ ${ }^{4}$ University Clinic for Neurosurgery, Faculty of Medicine, University Ss. Cyril and Methodius, Skopje, Republic of North Macedonia \\ ${ }^{5}$ Research Center for Genetic Engineering and Biotechnology "Georgi D. Efremov", Macedonian Academy of Sciences and \\ Arts, Skopje, Republic of North Macedonia
}

Corresponding author: Irina Panovska-Stavridis, $\mathrm{MD}, \mathrm{PhD}$, University Clinic of Hematology-Skopje, Republic of North Macedonia, Majka Tereza 17, 1000 Skopje, RN Macedonia, tel/fax:+389 2 3111749, e-mail: dr_irina@yahoo. com;

\section{ABSTRACT}

The outbreak of the COVID-19 pandemic has generated the largest global health crisis of the 21st century, evolving into accelerating socioeconomic disruption. In spite of all rapidly and widely emerging scientific data on epidemiology, diagnosis, prevention and treatment of the COVID-19 disease, severe acute respiratory coronavirus 2 (SARS-CoV-2) is continuing to propagate in lack of definitive and specific therapeutic agents. Current therapeutic strategies are mainly focused on viral inhibition by antiviral drugs and hampering the exuberant immune response of the host by immunomodulatory drugs. In this review, we have studied the reports of the largest clinical trials intended to COVID-19 treatment published during the first year of the pandemics. In general, these results concentrate on seven therapeutic options: remdesivir, chloroguine/hydroxychloroquine, lopinavir-ritonavir combination, corticosteroids, tocilizumab, convalescent plasma and monoclonal antibodies. In line with the reviewed data, as of January 2021, most of the evidence support the use of remdesivir in hospitalized patients with moderate and severe forms of the disease and provide reliable data on the substantial beneficial effect of corticosteroids in patients requiring supplemental oxygen. Moreover, preliminary RECOVERY trial results have demonstrated the efficacy of tociluzumab in the treatment of critically ill patients. The reports presenting the outcomes of the other immune-based therapies under investigation are enthusiastically awaited.

Keywords: SARS-CoV-2, COVID-19, pandemic, antiviral drugs, immunomodulatory drugs, remdesivir

\section{INTRODUCTION}

An emerging pandemic, initiated by a novel pathogen can cause severe burden on public health, accompanied by consecutive economic disruption. Therefore, rapid and insightful response in developing or repurposing existing therapeutic drugs or preventive vaccines is essential to the efforts to alleviate the negative consequences and to make the ongoing pandemic more manageable.

Due to its high transmission rate observed also in asymptomatic patients and substantial intrinsic virulence [1], severe acute respiratory coronavirus 2 (SARS-CoV-2), a $\beta$-coronavirus 
genetically clustered in subgenus Sarbecovirus [2], has already infected more than 102 million people, resulting in more than 2.2 million deaths reported worldwide (as of end January 2021). This unfavorable pattern of the virus biology can be perceived by the warning alarms and the detailed information on the disease spreading reported by the World Health Organization (WHO). According to WHO first reports on local outbreak of atypical viral pneumonia were linked to a wholesale wet market in Wuhan (Hubei, People's Republic of China) in late December 2019; subsequently, the novel coronavirus that probably spilled-over animal-to-human was identified by the Chinese Centre for Disease Control in early January 2020 [3]. Only a few weeks later, on 30 January 2020, WHO declared the novel coronavirus outbreak a Public Health Emergency of International Concern (PHEIC) [4]. On 11 February 2020, WHO chose the name of the novel disease - coronavirus disease 2019 (COVID-19), focusing on the etiology of the disease and the year the first cases were described. The International Committee on Taxonomy of Viruses (ICTV) thereafter named the virus "severe acute respiratory syndrome coronavirus 2 (SARS-CoV-2)" [2]. On 11 March 2020, following a rapid and sharp increase in the number of observed cases in 114 affected countries, WHO made an evaluation that COVID-19 met the criteria for a pandemic [4].

For years, coronaviruses affecting humans were believed to cause only mild cold symptoms. Then, two $\beta$-coronaviruses, phylogenetically related to SARS-CoV-2, severe acute respiratory coronavirus (SARS-CoV) in 2003 and middle east respiratory coronavirus (MERS-CoV) in 2014 led to outbreaks reaching mortality rate of $9.6 \%$ and $34.4 \%$ respectively. Compared to those, so far, SARS-CoV-2 demonstrates lower case fatality rates. However, its considerable spreading capacity leading to high human-to-human transmission rate represents the main aspect of the vast death toll of the present-day pandemic [5].

It is well known that spike (S) glycoprotein of SARS-CoV-2 envelope is responsible for successive binding to angiotensin-converting enzyme 2 (ACE2) receptor. The S protein has two functional subunits of which the first one $-\mathrm{S} 1$ subunit comprises the receptor binding domain (RBD). Consecutive membrane fusion and cellular uptake of the virus is achieved by endocytosis via various endocytic pathways [6]. ACE2 is practically found in all tissues but it is dominantly expressed in type I and type II alveolar epithelial cells in lungs, endothelial and smooth muscle cells in blood vessels, in kidneys and in small intestines. Such tissue distribution partly explains clinical findings observed in severe forms of the disease: extensive pulmonary consolidation and diffuse alveolar damage leading to respiratory distress; systemic vasculitis and renal insufficiency [6]. Emerging data show that SARS-CoV-2 infection may also lead to cardiac damage in severe cases or cause severe neurological symptoms [7]. Immune response is triggered when virus enters the host cells by activation of the innate immune system and stimulation of antiviral defense mechanisms including natural killer and $\mathrm{T}$ cells and interferon (IFN) secretion [8].

In lack of specific therapeutic drugs, repurposing the existing drugs originally approved for other diseases/indications by the global regulatory authorities remains the best treatment option for COVID-19. Unapproved drugs originally developed for the treatment of other diseases with a lack of evidence in its intended use are also taken into consideration. Current approaches to COVID-19 therapies generally fall into two categories: antiviral drugs - which inhibit viral replication by direct targeting of the virus - and immune modulators - which support the immune system of the host or hamper the overexpressed immune response in severely and critically ill patients. Some of the investigated agents may act in a different way or in various mechanisms simultaneously.

Up to date there are thousands of clinical trials for COVID-19 therapies across the world. By 15 June 2020, the European Medicines Agency (EMA) had approached developers of 132 potential COVID-19 treatments and by the end of January 2021, there are 82 therapeutics that have received EMA advice in over 39,000 clinical trials in the EU Clinical Trial Register [9].

\section{LARGEST CLINICAL TRIALS EVALUATING COVID-19 TREAT- MENT}

On 19 March 2020, the 'Randomized Evaluation of COVid-19 thERApY trial' (RECOVERY) was launched in the United Kingdom and as of January 2021 it has enrolled over 30,000 hospitalized COVID-19 patients from more than 170 
active sites. RECOVERY is an adaptive, randomized, open-label, controlled study and currently is the largest clinical trial investigating the effects of different treatment options on the outcome in patients with severe disease. Patients are randomized to standard care or one of the following ten studyarms: lopinavir/ritonavir, corticosteroid, hydroxychloroquine, azithromycin, tociluzimab, synthetic neutralizing antibodies (REGN-COV2), convalescent plasma, intravenous immunoglobulin, aspirin or colchicin plus standard hospital care [10-13].

On 20 March 2020, WHO presented SOLIDARITY trial, an international, adaptive, randomized, open-label, multi-center, phase III-IV clinical trial comparing the outcomes in patients receiving standard hospital care alone to patients receiving, in addition, one of the following treatments: remdesivir; chloroquine/ hydroxychloroquine, lopinavir/ritonavir and interferon- $\beta$ - 1 a plus lopinavir/ritonavir. As of 2 October 2020, 12,000 hospitalized patients in 500 different active hospital sites around 30 countries were enrolled. The interim results of this trial are presented in table 1-4 and discussed below in context of antiviral drugs [14].

On 22 March 2020, another large interventional trial, the European SOLIDARITY counterpart was announced by the French National Institute of Health and Medical Research (Institut National de la Santé et de la Recherche Médicale - INSERM). DisCoVeRy trial ("Trial of Tretments for COVID-19 in Hospitalized Adults") is an adaptive, multi-center clinical trial, which entails 4 treatment modalities, including remdesivir, lopinavir/ritonavir, lopinavir/ritonavir plus interferon $\beta$ and hydroxychloroquine, compared to standard care each [15].

During the pandemic, various smaller-size clinical trials for COVID-19 management have been commenced, especially in hardly affected countries, at first in China and then in European countries such as Italy, Spain, France and the UK and later in The United States. Those trials provide an efficient way of establishing the efficiency of experimental drugs, therefore offering a valuable screening for the most promising therapies and a basis for further larger clinical trials $[16,17]$. In addition, recent SARS and MERS epidemics, followed by extensive in vitro and in vivo studies, notably contribute to the selection of the most promising drugs for evaluation. Furthermore, some third world countries such as Brazil, Argentina, Colombia and Bangladesh also conducted trials with different drugs which will not be considered in our review due to significant methodological limitations and insufficient information on those studies [18].

\section{AIM}

As of January 2021, some preliminary results of the studies launched at the beginning of the pandemic are accessible promoting a more comprehensive insight in COVID-19 management. The aim of this review is to analyze available reports of some of the largest clinical trials evaluating COVID-19 treatment options.

\section{ANTIVIRAL DRUGS INVESTIGAT-} ED IN COVID-19 CLINICAL TRIALS

As the race for COVID-19 vaccine tightened and the "front-runners" were recognized, therapeutic switching of existing antiviral agents remained the fastest and safest approach in feasible management of the ongoing pandemic. We hereby highlight the most important data from clinical trials on the most investigated antiviral drugs in COVID-19.

\section{Remdesivir}

Remdesivir is one of the oldest nucleoside analogs with broad antiviral spectrum. Remdesivir inhibits RNA-dependent RNA polymerase triggering premature termination of viral RNA transcription, followed by ineffective replication [19]. In addition remdesivir shows high selectivity for viral RNA polymerase hence low leveltoxicity is expected in humans. Remdesivir was originally developed for the treatment of Ebola and it showed potent in vitro inhibitory activity (GS-5734) against Ebola virus and other flavoviruses. Although preclinical trials in Rhesus monkeys came with promising results [19] a randomized controlled trial conducted in Democratic Republic of Congo during the local Ebola outbreak reported a mortality rate of $53 \%$ in remdesivir-treated patients and remdesivir was dropped out of the study [20]. The idea of remdesivir use in the treatment of COVID-19 was encouraged by in vitro studies demonstrating its inhibitory activity against SARS-CoV and MERS-CoV [21]. 
Table 1. Overview of the largest clinical trials in COVID-19 investigating Remdesivir

\begin{tabular}{|c|c|c|c|c|}
\hline $\begin{array}{l}\text { Study/ Design } \\
\text { No of patients }\end{array}$ & $\begin{array}{c}\text { Start-up date } \\
\text { Completion date }\end{array}$ & Outcomes & $\begin{array}{l}\text { Intervention/ } \\
\text { treatment }\end{array}$ & Results \\
\hline \multicolumn{5}{|c|}{ Remdesivir (RDV) } \\
\hline $\begin{array}{l}\text { WHO Solidarity } \\
\text { (NCT04647669) } \\
\text { [14] } \\
\text { multicentre adaptive } \\
\text { international } \\
\text { open labeled } \\
\text { randomized placebo- } \\
\text { controlled, phase III } \\
(\mathbf{n}=\mathbf{2 7 5 0 )}\end{array}$ & $\begin{array}{l}\text { 18.03. } 2020- \\
\text { ongoing }\end{array}$ & $\begin{array}{l}\quad \text { Primary: } \\
\quad \text { mortality } \\
\text { - Secondary: } \\
\text { - Hospital stay, } \\
\text { - Time to } \\
\text { ventilation; } \\
\text { - Time to ICU } \\
\text { admission }\end{array}$ & \multirow{2}{*}{$\begin{array}{l}\text { a) } \begin{array}{l}\text { Standard of care } \\
\text { (SOC) }\end{array} \\
\text { b) } \\
\text { Standard of care }+ \\
\text { Remdesivir } \\
\text { (200 mg loading } \\
\text { dose on Day 1, } \\
100 \mathrm{mg} \text { for } \\
\text { subsequent doses } \\
\text { from Day } 2 \text { up to } \\
\text { Day } 10\end{array}$} & $\begin{array}{cl}\text { Interim results }(02.12 .20): \\
\text { Remdesivir did not } \\
\text { significantly reduced: } \\
\text { - } \quad \text { Mortality rate } \\
& \text { (overall or in } \\
& \text { subgroups) } \\
\text { - } & \text { Hospital stay, } \\
\text { - } & \text { Initiation of } \\
& \text { ventilation } \\
\text { - } & \text { Admission to ICU }\end{array}$ \\
\hline $\begin{array}{c}\text { DisCoVeRy } \\
\text { [NCT04315948] } \\
{[15]} \\
\text { Multicentre adaptive } \\
\text { international } \\
\text { open labeled } \\
\text { randomized, placebo- } \\
\text { controlled phase III }\end{array}$ & $\begin{array}{l}20.03 .2020- \\
\text { ongoing }\end{array}$ & $\begin{array}{l}\text { Primary: } \\
\text { clinical status } \\
\text { at day } 15(7 \\
\text { point scale }) \\
17 \text { efficacy } \\
\text { and safety } \\
\text { endpoints }\end{array}$ & & No results posted \\
\hline $\begin{array}{c}\text { A Phase } 3 \\
\text { Randomized Study to } \\
\text { Evaluate the Safety } \\
\text { and Antiviral Activity } \\
\text { of Remdesivir } \\
(\text { GS-5734TM) in } \\
\text { Participants With } \\
\text { Moderate COVID-19 } \\
\text { Compared to } \\
\text { Standard of Care } \\
\text { Treatment } \\
\text { [NCT04292730] } \\
\text { [28] } \\
(\mathbf{n = 5 9 6 )}\end{array}$ & $\begin{array}{l}15.03 .2020- \\
29.04 .2020\end{array}$ & $\begin{array}{l}\text { Primary: } \\
\text { clinical status } \\
\text { at day } 11 \\
\text { (7 point scale) } \\
\text { Secondary: } \\
\text { adverse effects } \\
\text { no later than } \\
30 \text { days of first } \\
\text { RDS dose) }\end{array}$ & $\begin{array}{l}\text { a) Standard of care } \\
\text { b) Standard of care }+ \\
\text { Remdesivir ( } 200 \mathrm{mg} \\
\text { loading dose on Day } 1 \text {, } \\
100 \mathrm{mg} \text { for subsequent } \\
\text { doses for } 4 \text { Days) } \\
\text { c) Standard of care }+ \\
\text { Remdesivir ( } 200 \mathrm{mg} \\
\text { loading dose on Day } 1 \text {, } \\
\text { 100mg for subsequent } \\
\text { doses for } 9 \text { days) }\end{array}$ & $\begin{array}{l}\text { Published on } 15.09 .20: \\
\quad 5 \text { days course of } \\
\text { Remdesivir was } \\
\text { associated with higher } \\
\text { odds of improvement } \\
\text { at day } 11 . \\
\text { AE were more } \\
\text { common in } 10 \text { days } \\
\text { course of RDS than } \\
\text { SOC group }(p<0.05)\end{array}$ \\
\hline $\begin{array}{c}\text { A Phase } 3 \\
\text { Randomized Study to } \\
\text { Evaluate the Safety } \\
\text { and Antiviral Activity } \\
\text { of Remdesivir } \\
(\text { GS-5734TM) in } \\
\text { Participants With } \\
\text { Severe COVID-19 } \\
\text { [NCT04292899] } \\
\text { [29] } \\
(\mathbf{n = 3 9 7 )}\end{array}$ & $\begin{array}{l}06.03 .2020- \\
09.04 .2020\end{array}$ & $\begin{array}{l}\text { Primary: } \\
\text { clinical status } \\
\text { at day } 14 \\
\text { (7 point scale) } \\
\text { Secondary: } \\
\text { adverse effects } \\
\text { ( no later than } \\
30 \text { days of first } \\
\text { RDS dose) }\end{array}$ & $\begin{array}{l}\text { a) Standard of care }+ \\
\text { Remdesivir ( } 200 \mathrm{mg} \\
\text { loading dose on Day } 1 \text {, } \\
100 \mathrm{mg} \text { for subsequent } \\
\text { doses for } 4 \text { Days) } \\
\text { b) Standard of care }+ \\
\text { Remdesivir ( } 200 \mathrm{mg} \\
\text { loading dose on Day } 1 \text {, } \\
\text { 100mg for subsequent } \\
\text { doses for } 9 \text { days) }\end{array}$ & $\begin{array}{l}\text { Published on 27.05.20: } \\
\text { There was no } \\
\text { significant difference } \\
\text { between 5- and } 10 \\
\text { days course of RDS at } \\
\text { day } 14 \\
\text { There was no } \\
\text { difference of AE } \\
\text { occurrence in both } \\
\text { groups }\end{array}$ \\
\hline $\begin{array}{c}\text { ACTT } \\
\text { [NCT04280705] } \\
\text { [27] } \\
\text { adaptive, randomized, } \\
\text { double-blind, } \\
\text { placebo-controlled } \\
\text { trial } \\
(\boldsymbol{n}=\mathbf{1 0 6 2})\end{array}$ & $\begin{array}{l}21.02 .2020- \\
21.05 .2020\end{array}$ & $\begin{array}{l}\text { Primary: time } \\
\text { to recovery } \\
\text { 24 efficacy } \\
\text { and safety } \\
\text { endpoints }\end{array}$ & $\begin{array}{l}\text { a) Remdesivir } \\
\text { (200 mg loading } \\
\text { dose on Day 1, } \\
\text { 100mg for } \\
\text { subsequent doses } \\
\text { from Day } 2 \text { up to } \\
\text { Day } 10 \\
\text { b) Placebo }\end{array}$ & 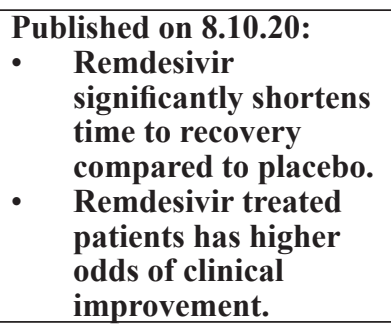 \\
\hline
\end{tabular}

The trials are shown with clinicalTrials.gov identifier number

*The number of participants in brakes is the number of the patients included in the specific therapeutic arm. 
Furthermore, the results of a comparative study on the in vitro and in vivo antiviral activity of selected drugs against MERS-CoV were published just a few days after the identification of SARSCoV-2 [22]. According to the study remdesivir was correlated with significant improvements in immunological and clinical features in MERS$\mathrm{CoV}$ infected mice. Following COVID-19 outbreak in China, the manufacturer of remdesivir, Gilead Sciences showed an increased interest in this drug and by the end of June 2020 over 190.000 treatment courses of remdesivir were produced. The first study to demonstrate potent in vitro activity of remdesivir against SARSCoV-2 was performed during the first months of the pandemic in China [23].

The first successful administration of remdesivir via compassionate use protocol was reported in the USA in a 35-year-old man who developed pneumonia after a recent visit to Wuhan, China. In fact it was the first confirmed case of COVID-19 in the USA. The succeeding report on the first 12 COVID-19 cases in the USA, of which 3 patients received remdesivir on compassionate base in the course of 4 to 10 days described improvement in respiratory symptoms [24]. Data from a cohort study of 53 individuals with severe COVID-19 treated with remdesivir via compassionate protocol, showed a significant, 68\% oxygenation status improvement. Over a median follow-up of 18 days, lethal outcome was noted in $13 \%$, a significantly lower rate compared to those observed in studies in patients with comparable clinical features receiving only standard care [25]. Even though the first randomized placebo-controlled trial conducted in 10 hospitals in Wuhan did not show any benefit from remdesivir treatment [26], by mid-April remdesivir was considered the most promising drug for severe COVID-19. As of April 2020, remdesivir was tested in two large clinical trials: SOLIDARITY trial [14] and DisCoVeRy trial [15] (Table 1).

The earliest positive reports on remdesivir efficiency in COVID-19 were published in the preliminary and final results of Adaptive COVID-19 Treatment Trial-1(ACTT-1) run by the National Institute of Allergy and Infectious Diseases (NIAID) (Table 1). ACTT-1 is the first US trial to evaluate experimental drugs in COVID-19. This trial enrolled 1,062 patients, $85 \%$ of whom had severe disease. The benefit of remdesivir was most evident in patients receiv- ing low-flow oxygen, possibly in part due to the larger sample size in this group [27]. These findings were encouraged by the two Gilead sponsored trials in moderate and severe COVID-19 pneumonia 28, 29] (Table 1).

On 1 May 2020, based on enclosed evidence in NIAID's trial, the US Food and Drug Administration (FDA) issued an emergency use authorization (EUA) for remdesivir in the treatment of severe COVID-19 [16]. In Europe, EMA started a 'rolling review' of the available data on the use of remdesivir in COVID-19 patients, which was completed in late May 2020. On 25 June 2020 EMA's Committee for Medical Products for Human Use (CHMP) granted Gilead conditional marketing authorization for remdesivir for the treatment of adults and adolescents with severe COVID-19 pneumonia, requiring oxygen supplementation. On 28 August 2020, FDA expanded the EUA to all hospitalized patients with COVID-19 regardless of the disease severity, raising concerns among experts in this field. Currently, remdesivir is the only drug approved for EUA by FDA in 50 countries and the only drug with conditional marketing authorization for COVID-19 treatment issued by EMA. On 22 October 2020, FDA approved remdesivir for the inpatient treatment of COVID-19 in adults and children over the age of 12 and weighing over $40 \mathrm{~kg}$, thus becoming the first and only treatment for COVID-19 approved by FDA [30]. As this approval does not cover all groups included in the previous one, FDA revised the EUA and issued a new EUA to provide access for the pediatric patients younger than 12 , weighing at least $3.5 \mathrm{~kg}$. EMA recommends initial administration of $200 \mathrm{mg}$ remdesivir infusion on day 1 followed by $100 \mathrm{mg}$ infusion per day for 4 , up to 9 days, as per clinical indication. Close monitoring of liver function is strongly advised [27].

However, the initial enthusiasm for remdesivir treatment in COVID-19 has lessened as the interim results from SOLIDARITY trial were released. This study found that all 4 treatments evaluated (remdesivir, hydroxychloroquine, lopinavir/ritonavir and interferon) had little or no effect on overall mortality, initiation of ventilation and duration of hospital stay in hospitalized patients [14]. As a result, on 20 December 2020, WHO renewed the guideline on clinical care for COVID-19 and adjoined a conditional recommendation against the use of remdesivir in all patients. WHO also considered other issues of 
remdesivir use, such as its high price, the limited drug supply and regulatory processes [31]. Still, WHO recommendations confronted certain lack of conviction of the other international regulatory organizations. EMA asked for the complete WHO study data in order to review the evidence and the related data before making any changes of the Remdesivir status in Europe. The results from the DisCoVeRy trial might clarify some of the contraversies concerning these discrepancies and they are eagerly awaited. Still, in the middle of a raging pandemic, remdesivir remains in the focus of the treatment of moderately and severely ill COVID-19 patients who may benefit from early treatment initiation. Its role will to a large extent depend on the design of future studies whether future studies will investigate remdesivir efficacy in COVID-19 treatment and whether remdesivir will be further compared to placebo in controlled randomized trials. As of May 2020, ACTT-2 trial is investigating the effectiveness of remdesivir monotherapy compared to the combination of remdesivir and Janus Kinase (JAK) inhibitor baricitinib in hospitalized patients with COVID-19 [32].

\section{Chloroquine and hydroxychloroquine}

During the very first weeks of the SARSCoV-2 outbreak, the antimalarial drug chloroquine was tested in numerous clinical trials for COVID-19. In vitro studies demonstrated its potential to inhibit the endosomal acidification and glycosylation of ACE2 receptors, preventing subsequent viral invasion of human cells [23]. In mid-February, a Chinese study including 100 patients showed superiority of chloroquine over control treatment in preventing disease progression in COVID-19 and facilitation of clinical presentation. Severe adverse effects of chloroquine were not observed in this study [33]. Due to possible cardiovascular adverse effects and supply shortages of chloroquine, an alternative drug, a chloroquine derivate - hydroxychloroquine, was proposed. This drug has an improved safety profile and it is currently used in rheumatic conditions. According to two in vitro studies, hydroxychloroquine showed 5-fold increased inhibitory activity against SARS-CoV in Vero cells vs. chloroquine $[34,35]$. The earliest reports on hydroxychloroquine efficiency in COVID-19 were inconsistent. A small, open-label French clinical trial showed faster viral clearance in hydroxychloroquine + azithromycin treated pa- tients reaffirmed in the follow-up period, in contrast, to other clinical studies at the same time that found no difference in viral eradication and clinical outcome [36]. Preliminary results of a small preclinical study reported no beneficial effects on viral replication and disease outcome in prophylactically or therapeutically treated animal models with hydroxychloroquine [37].

Hydroxychloroquine was included in three large trials: SOLIDARITY, DISCOVERY and RECOVERY. On 5 June 2020 and 4 July 2020 investigators of RECOVERY and SOLIDARITY trials stopped patients' enrolling in the hydroxychloroquine arm based on data presented in Table 2 [10, 14]. Similarly, on 15 June 2020 FDA revoked the EUA of chloroquine and hydroxychloroquine in the USA stating that criteria for issuing EUA are no longer met. In the meantime, two randomized trials demonstrating no beneficial effects of hydroxychloroquine in outpatients with mild symptoms were also published [38, 39].

\section{Lopinavir/ritonavir}

In accordance with the observed in vitro inhibitory activity against SARS-CoV, an attempt for lopinavir repurposing in COVID-19 treatment was highly expected. Lopinavir is an antiretroviral drug commonly used in Human Immunodeficiency Syndrome (HIV) management usually in combination with ritonavir which increases the plasma half-life of lopinavir by cytochrome CYP3A4 inhibition. Previous in vitro studies of SARS-CoV and MERS-CoV showed that lopinavir targets papain-like proteases and 3C-like proteases in coronaviruses [40]. A Chinese study proved a significant difference in mortality between the initial lopinavir/ritonavir group and the control group in SARS patients. This difference was not noticed in the rescue-lopinavir/ritonavir-group. However, patients in this study received ribavirin and steroids which may interfere with the antiviral activity of lopinavir [41].

One of the earliest Chinese randomized trials failed to demonstrate a beneficial effect of lopinavir/ritonavir in COVID-19 [42]. Yet this drug combination was included in all of the largest trials. The discouraging final results of the RECOVERY trial were published in October (Table 3) [11]. The enrollment of patients in this study arm was terminated on 29 June 2020, ensuing detailed analysis of interim results. On 4 July 2020, assessing the reports from numer- 
Table 2. Overview of the largest clinical trials in COVID-19 investigating Chloroquine and Hydroxychloroquine.

\begin{tabular}{|c|c|c|c|c|}
\hline $\begin{array}{l}\text { Study/ Design } \\
\text { No of patients }\end{array}$ & $\begin{array}{c}\text { Start-up date } \\
\text { Completion date }\end{array}$ & Outcomes & $\begin{array}{c}\text { Intervention/ } \\
\text { treatment }\end{array}$ & Results \\
\hline \multicolumn{5}{|c|}{ Chloroquine and hydroxychloroquine } \\
\hline $\begin{array}{c}\text { RECOVERY } \\
\text { [NCT04381936] } \\
{[10]} \\
(n=4716) *\end{array}$ & $\begin{array}{l}11.05 .2020- \\
\text { ongoing } \\
\text { Arm } \\
\text { terminated on } \\
05.20 .20\end{array}$ & \multirow{2}{*}{$\begin{array}{l}\text { - Primary: mortality } \\
\text { - Secondary: } \\
\text { - Hospital stay, } \\
\text { - Time to ventilation; } \\
\text { - Time to ICU } \\
\text { admission }\end{array}$} & \multirow{3}{*}{$\begin{array}{l}\text { a) Standard of care } \\
\text { b) Standard of care }+ \\
\text { Hydroxychloroquine } \\
\text { per os for a total of } 10 \\
\text { days ( } 800 \mathrm{mg} \text { day } 1 \text { and } \\
400 \mathrm{mg} \text { day } 2-10)\end{array}$} & $\begin{array}{l}\text { Published on } 17.11 .2020 \\
\text { Hydroxychloroquine did } \\
\text { not reduce mortality rate. } \\
\text { No benefit was observed in } \\
\text { secondary outcomes. }\end{array}$ \\
\hline $\begin{array}{c}\text { WHO Solidarity } \\
\text { (NCT04647669) } \\
{[14]} \\
(n=954)\end{array}$ & $\begin{array}{l}\text { 18.03. } 2020- \\
\text { ongoing } \\
\text { Arm } \\
\text { terminated on } \\
04.06 .20\end{array}$ & & & $\begin{array}{l}\text { Interim results }(02.12 .20) \text { : } \\
\text { Hydroxychloroquine did } \\
\text { not reduce mortality rate. } \\
\text { No benefit was observed in } \\
\text { secondary outcomes. }\end{array}$ \\
\hline $\begin{array}{c}\text { DisCoVeRy } \\
\text { [NCT04315948] } \\
{[15]}\end{array}$ & $\begin{array}{l}20.03 .2020- \\
\text { ongoing } \\
\text { Arm } \\
\text { terminated on } \\
24.05 .20\end{array}$ & $\begin{array}{l}\text { Primary: clinical } \\
\text { status at day } 15 \text { ( } 7 \\
\text { point scale) } \\
17 \text { efficacy and } \\
\text { safety endpoints }\end{array}$ & & No official results posted \\
\hline
\end{tabular}

Table 3. Overview of the largest clinical trials in COVID-19 investigating Lopinavir/Ritonavir

\begin{tabular}{|c|c|c|c|c|}
\hline $\begin{array}{l}\text { Study/ Design } \\
\text { No of patients }\end{array}$ & $\begin{array}{c}\text { Start-up date } \\
\text { Completion date }\end{array}$ & Outcomes & $\begin{array}{c}\text { Intervention/ } \\
\text { treatment }\end{array}$ & Results \\
\hline \multicolumn{5}{|c|}{ Lopinavir/Ritonavir } \\
\hline $\begin{array}{c}\text { RECOVERY } \\
\text { [NCT04381936] } \\
\text { [11] } \\
(\mathrm{n}=1616)\end{array}$ & $\begin{array}{c}11.05 .2020- \\
\text { ongoing } \\
\text { Arm terminated on } \\
29.06 .20\end{array}$ & \multirow{2}{*}{$\begin{array}{c}\text { Primary: } \\
\text { mortality } \\
\text { Secondary: } \\
\text { - Hospital stay, } \\
\text { - Time to ventilation; } \\
\text { - Time to ICU } \\
\text { admission }\end{array}$} & \multirow{3}{*}{$\begin{array}{l}\text { a) Standard of } \\
\text { care } \\
\\
\text { b) Standard of } \\
\text { care }+ \\
\text { Lopinavir } \\
\text { 400mg-Ritonavir } \\
\text { 100mg per os } \\
\text { twice per day for } \\
10 \text { days. }\end{array}$} & $\begin{array}{l}\text { Published on } 5.10 .2020 \\
\text { Lopinavir/ritonavir did } \\
\text { not reduce mortality rate. } \\
\text { No benefit was observed } \\
\text { in secondary outcomes. }\end{array}$ \\
\hline $\begin{array}{c}\text { WHO Solidarity } \\
\text { (NCT04647669) } \\
{[14]} \\
(n=1411)\end{array}$ & $\begin{array}{c}18.03 .2020- \\
\text { ongoing } \\
\text { Arm terminated on } \\
04.06 .20\end{array}$ & & & $\begin{array}{c}\text { Interim results }(02.12 .20) \text { : } \\
\text { Lopinavir/Ritonavit did } \\
\text { not reduce mortality rate. } \\
\text { No benefit was observed } \\
\text { in secondary outcomes. }\end{array}$ \\
\hline $\begin{array}{c}\text { DisCoVeRy } \\
\text { [NCT04315948] } \\
{[15]}\end{array}$ & $\begin{array}{c}20.03 .2020- \\
\text { ongoing } \\
\text { Arm terminated on } \\
24.05 .20\end{array}$ & $\begin{array}{c}\text { Primary: } \\
\text { clinical status at } \\
\text { day } 15 \text { ( } 7 \text { point } \\
\text { scale) } \\
17 \text { efficacy and } \\
\text { safety endpoints }\end{array}$ & & No official results posted \\
\hline
\end{tabular}

ous hospitals, enrolled in the SOLIDARITY trial, WHO announced an immediate termination of the lopinavir/ritonavir arm due to lack of firm evidence on survival benefit.

\section{Favipiravir}

Favipiravir, originally approved for influenza in Japan in 2014, emerged as one of the treatments repurposed for COVID-19. However, only limited clinical experience is reported in the setting of COVID-19 since it is not evaluated in any of the largest clinical trials discussed hereby. The mechanism of its action is similar to remdesivir but when compared to remdesivir there are less powerful data to support its clinical use. The preliminary results from smaller clinical trials in Russia, China and Japan encourage the use of favipiravir in mild and moderate disease as it appears to shorten the viral shedding time and symptoms duration [43]. There are over 40 ongoing trials evaluating the efficacy and safety of favipiravir in COVID-19 which are expected to 
further define the role of favipiravir in the management of COVID-19.

\section{IMUNOMODULATORY DRUGS USED IN COVID-19 CLINICAL TRIALS}

Blood samples studies of severely ill COVID-19 patients demonstrated increased interleukin (IL)-2 and IL-7 levels, as well as elevated granulocyte colony stimulating factor, interferon- $\mathrm{Y}$, inducible protein 10 , tumor necrosis factor- $\alpha$, macrophage inflammatory protein 1- $\alpha$ and monocyte chemoattractant protein-1. Poor disease outcome was associated with elevated ferritin and IL-6 concentrations suggesting the essential role of hyper-inflammation in the disease's course and outcome [44]. Presumably, the aberrant immune response in COVID-19 leading to hyperinflammation and cytokine storm can be restrained by immunomodulatory agents such as steroids, interleukin receptor blockers, JAK inhibitors or immunoglobulins. The following part of this paper reviews the most studied immunomodulatory drugs for COVID-19.

\section{Corticosteroids}

There are various reports on corticosteorids efficiency in SARS patients. A few trials showed no impact on clinical outcome, while others demonstrated decreased mortality rate [45]. On the other hand, there are studies documenting worse outcomes in SARS patients treated with steroids [46]. According to a large cohort, steroids were associated with delayed viral eradication in MERS-CoV patients [47].

Considering the conflicting reports in SARS and MERS, treatment with steroids in the earliest days of COVID-19 outbreak was taken with extreme caution. In a Chinese cohort study in March 2020, methylprednisolone administration in COVID-19 patients was associated with increased risk of ARDS which most likely occurred due to the fact that the most severely ill patients received steroids. However, methylprednisolone decreased the risk of fatal outcome in patients with ARDS. Soon afterwards, the Chinese Thoracic Society warned of appropriate steroid dosing in COVID-19 patients taking into consideration the onset and duration of symptoms, clinical presentation, comorbidities, rec- ommending lower doses ( $\leq 0.5$ to $1 \mathrm{mg} / \mathrm{kg}$ daily) of methylprednisolone for up to 7 days [48].

Initiators of SOLIDARITY and DISCOVERY trials did not recognize the potency of steroids in COVID-19 treatment and they were not included in the initial study modalities. In contrast, RECOVERY trial did evaluate dexamethasone for COVID-19 treatment. A preliminary report from the dexamethasone arm of this trial is probably the brightest announcement emerging from the largest COVID-19 clinical trials, appointing it as the only drug proved to significantly decrease mortality rates in the setting of COVID-19 (Table 4). This effect was observed in patients requiring supplemental oxygen. However, the study does not indicate the level of oxygen support, an important parameter to further define the patients who mostly benefit from steroids treatment [12].

The RECOVERY trial was identified as a turning point in the actual clinical practice for hospitalized patients receiving oxygen support. Dexamethasone is not recommended for patients not requiring supplemental oxygen. A few questions remain unchallenged. The benefit from steroids treatment combined with remdesivir is not sufficiently investigated in clinical trials. Moreover, patients are excluded from trials with corticosteroids in presence of clear contraindications and also when considered unsuitable for steroid treatment by investigators. A thorough risk-benefit assessment is required in order to better define patients who might benefit from steroid treatment. Finally, various clinical data raise issues for further evaluation of steroid pulse therapy effects in hyper-inflammation phase of COVID-19, similar to the scheme used in systemic autoimmune disease. A small Iranian randomized clinical trial demonstrated a significant reduction in mortality and improved clinical and laboratory findings in patients with severe COVID-19 at the early pulmonary phase of the disease treated with methylprednisolone pulse, compared to standard care group [49].

\section{Toclizumab}

Two studies on tocilizumab in severely ill COVID-19 patients published in mid-July by American and Italian researchers revealed a potential game-changer in COVID-19 management $[50,51]$. Tocilizumab is a recombinant humanized monoclonal antibody approved for the treatment of severe rheumatoid syndromes and cytokine release syndrome induced by chime- 
ric antigen receptor (CAR) T-cell therapy [51]. Tocilizumab binds to IL-6 receptors which may contribute to gradual extinguishing of cytokine storm observed in critically ill COVID-19 patients. The beneficial effect in COVID-19 management was initially recognized in a single-centre study conducted in Wuhan, which encouraged Italian clinicians to precede an off-label use of tocilizumab in treatment of patients with severe COVID-19 pneumonia. Data from a retrospective observational cohort study of 544 patients from North Italy hospitalized during late February and late April 2020 confirmed the previous findings. According to issued reports, intravenous or subcutaneous administration of tocilizumab is likely associated with a decreased risk of progression to invasive ventilation or death in patients with severe respiratory symptoms. More precisely, $20 \%$ of patients who received only standard care died, versus $7 \%$ of patients treated with tocilizumab [52].

According to a recent American study, tocilizumab usage in severe COVID-19 is attributed to a double increase in frequency of superinfections ( $54 \%$ vs $26 \%$; $<<0.001)$ especially among patients requiring mechanical respiratory support. Despite that finding co-infection did not significantly affect the 28-day survival rate. Both groups had similar clinical, laboratory and immune-pathological features at admission. An Italian single-centre study also observed lower mortality rates in the tocilizumab group than in the control group. In the first study, secondary outcomes such as a hospitalization need at the end of the follow-up, were significantly lower in the tocilizumab group, while the Italian study observed more frequent respiratory super-infections, leading to significantly delayed duration of hospitalization in this group $[50,51]$. In contrast, data from controlled randomized trials, such as the Hoffmann-La Roche sponsored trial - COVACTA [53] and the Massachusetts General Hospital trial [54] were discouraging. Tocilizumab did not improve survival and did not reduce the risk of disease progression. The preliminary results for RECOVERY trial in twice as many patients were published preprint on 12 February, reporting the clearest evidence of tocilizumab benefit in patients with hypoxia and systemic inflammation. More precisely, tocilizumab enhances survival and decreased the risk of disease progression [13] (Table 4). Further work is still necessary to determine the patients most likely to benefit from tocilizmab

Table 4. Overview of the largest clinical trials in COVID-19 investigating imunomodulatory drugs: Dexamethasone, Tocilizumab and convalescent plasma

\begin{tabular}{|c|c|c|c|c|}
\hline $\begin{array}{l}\text { Study/ Design } \\
\text { No of patients }\end{array}$ & $\begin{array}{c}\text { Start-up date } \\
\text { Completion date }\end{array}$ & Outcomes & $\begin{array}{c}\text { Intervention/ } \\
\text { treatment }\end{array}$ & Results \\
\hline \multicolumn{5}{|c|}{ Dexamethasone } \\
\hline $\begin{array}{c}\text { RECOVERY } \\
\text { [NCT04381936] } \\
{[12]} \\
(n=2104)\end{array}$ & $\begin{array}{l}11.05 .2020- \\
\text { ongoing }\end{array}$ & $\begin{array}{l}\text { Primary: mortality } \\
\text { at } 28 \text { days } \\
\text { - } \quad \text { Secondary: } \\
\text { - Hospital stay, } \\
\text { - Time to ventilation; } \\
\text { - Time to ICU admission }\end{array}$ & $\begin{array}{l}\text { a) Standard of care } \\
\text { b) Standard of care }+ \\
6 \mathrm{mg} \text { Dexamethasone } \\
\text { or equivalent dose of } \\
\text { steroids for } 10 \text { days }\end{array}$ & $\begin{array}{l}\text { Published on } 17.06 .20: \\
\text { Dexamethasone } \\
\text { significantly reduced } \\
\text { mortality rate at } 28 \text { days } \\
\text { in patients requiring } \\
\text { supplemental oxygen }\end{array}$ \\
\hline \multicolumn{5}{|c|}{ Tocilizumab } \\
\hline $\begin{array}{c}\text { RECOVERY } \\
\text { [NCT04381936] } \\
{[13]}\end{array}$ & $\begin{array}{l}11.05 .2020- \\
\text { ongoing }\end{array}$ & $\begin{array}{l}\text { Primary: mortality } \\
\quad \text { at } 28 \text { days } \\
\text { - Secondary: } \\
\text { - Hospital stay, } \\
\text { - Time to ventilation; } \\
\text { ICU }\end{array}$ & $\begin{array}{l}\text { a) Standard of care } \\
\text { b) Standard of care }+ \\
\text { Tocilizumab per kg/ } \\
\text { TT i.v. }\end{array}$ & $\begin{array}{l}\text { Preprint of 12.02.2021 } \\
\text { Tocilizumab significantly } \\
\text { improved survival and } \\
\text { secondary outcomes in } \\
\text { patients with hypoxia and } \\
\text { systemic inflammation }\end{array}$ \\
\hline
\end{tabular}

Convalescent plasma

\begin{tabular}{c|c|l|l|l}
\hline $\begin{array}{c}\text { RECOVERY } \\
\text { [NCT04381936] }\end{array}$ & $\begin{array}{c}\text { Primary: mortality } \\
\text { at Secondary: } \\
\text { ongoing }\end{array}$ & $\begin{array}{l}\text { a) Standard of care } \\
\text { - Hospital stay, } \\
\text { - Time to ventilation; } \\
\text { ICU }\end{array}$ & $\begin{array}{l}\text { b) Single plasma unit } \\
\text { on day 1 and } 2\end{array}$
\end{tabular} \mid $\begin{aligned} & \text { No results published } \\
& \text { and }\end{aligned}$


treatment, time totreatment and administration of tocilizumab with antiviral drugs.

\section{Convalescent plasma}

Administration of convalescent plasma derives from the hypothesis that antibodies in the plasma of patients recovering from viral infection can suppress viremia. Treatment with convalescent plasma was previously reported in various viral infections, such as $\mathrm{H}_{5} \mathrm{~N}_{1}$ avian influenza, $\mathrm{H}_{1} \mathrm{~N}_{1}$ swine flu influenza, SARS and Ebola [55].

Even though earliest findings in China issued promising results, the first randomized trial demonstrated no benefit in clinical improvement of 52 severely ill COVID-19 patients compared to the standard care group. This trial included only 103 patients of the target of 200 patients to generate significant data, owing to suppression of Wuhan outbreak [56]. The Dutch randomized study was terminated prematurely as neutralizing antibodies against SARS-CoV-2 were detected in the majority of patients with median blood levels equal to donors' titers [57]. These findings questioned the benefit from convalescent plasma in hospitalized patients given that most of the patients have already generated antibodies. In addition, PLACID trial in India demonstrated no significant difference in disease severity and mortality rate in patients with moderate disease who received convalescent plasma. In this trial however, the levels of specific antibodies were not tested at first [58]. The most recent data from the largest trial - Plas$\mathrm{mAR}$ trial were consistent with previous findings [59]. Convalescent plasma is investigated in the DISCOVERY trial and preliminary results are not currently available.

\section{Casirivimab/imdevimab}

(Regeneron)- REGNCOV2

REGN-COV2 is a novel experimental mixture of two monoclonal antibodies evaluated as part of the RECOVERY trial as of September 2020. In an interim analysis, the REGN-COV2 antibody cocktail was found to reduce the viral load, with a greater effect in patients whose immune response had not yet been initiated or who had high viral load at baseline. Safety outcomes were similar in the combined REGN-COV2 dose groups and the placebo group [60]. On 21 November 2020, FDA issued EUA for the treatment of patients with mild and moderate disease with risk factors for progression.

\section{Bamlanivimab}

A few days earlier, another monoclonal antibody - bamlanivimab was granted EUA for the same indication by FDA. Bamlanivumab is a neutralizing antibody directed against the spike protein of SARS-CoV-2. It is investigated in several trials and although some of them show positive results in terms of lowering the viral load, further reports are essential to provide clinically applicable data [61].

\section{CONCLUSION}

Severely ill COVID-19 patients have overwhelmed the hospitals around the world. Almost a year later, therapeutic options remain considerably modest. Prompt screening of therapies is vital but challenging. Repurposing of approved drugs is an important strategic step because safety profiles of these drugs are well established. Several thousand clinical trials are currently enrolling patients in order to evaluate the in vivo activity of repurposed drugs. Nevertheless, there is no consistent guidance regarding initiation, duration of treatment and endpoints. Immunological and pathological mechanisms of the infection, as well as the association between clinical features and viral clearance are not fully understood, making defining clinical outcomes strongly recommended.

In an emerging pandemic of a novel pathogen, rapid evaluation of available data is crucial. The results of randomized trials provide rational guidance for clinical practice and robust high-grade information. The selection of drugs included in trials should be based on evident in vitro and in vivo activity in preclinical studies.

As of January 2021, three large, global, randomized trials have been launched. First insight into available data suggest that there is no clear evidence for potential benefit of hydroxychloroquine and lopinavir/ritonavir in therapeutic management of severely ill COVID-19 patients. At present, there is only evidence supporting the use of remdesivir in hospitalized patients and corticosteroids in patients requiring oxygen supplementation. In addition, preliminary results of the RECOVERY trial showed that tocilizum- 
ab decreases the risk of death among hospitalized patients with severe COVID-19, shortens recovery time and reduces the need for mechanical ventilation. Probably the most encouraging reports will emerge from studies on the rest of immune-based therapies, enlarging the eagerly awaited results from the largest randomized trial so far, the RECOVERY trial.

\section{REFERENCES}

1. Liu Y, Gayle AA, Wilder-Smith A, Rocklöv J. The reproductive number of COVID-19 is higher compared to SARS coronavirus. J Travel Med. 2020 Mar 13; 27(2): taaa021.

2. Coronaviridae Study Group of the International Committee on Taxonomy of Viruses. The species Severe acute respiratory syndrome-related coronavirus: classifying 2019-nCoV and naming it SARS-CoV-2. 2020; 5(4): 536-544.

3. Zhu N, Zhang D, Wang W, Li X, Yang B, Song J, Zhao X, Huang B, Shi W, Lu R, Niu P, Zhan F, Ma X, Wang D, Xu W, Wu G, Gao GF, Tan W; China Novel Coronavirus Investigating and Research Team. A Novel Coronavirus from Patients with Pneumonia in China, 2019. N Engl J Med. 2020 Feb 20; 382(8): 727-733.

4. Cucinotta D, Vanelli M. WHO Declares COVID-19 a Pandemic. Acta Biomed. 2020 Mar 19;91(1):157-160.

5. Gilbert GL. Commentary: SARS, MERS and COVID-19-new threats; old lessons. Int J Epidemiol. 2020 Jun 1; 49(3): 726-728.

6. Yan R, Zhang Y, Li Y, Xia L, Guo Y, Zhou Q. Structural basis for the recognition of SARSCoV-2 by full-length human ACE2. Science. 2020 March 27; 367(6485): 1444-1448.

7. Gupta, A., Madhavan, M.V., Sehgal, K. et al. Extrapulmonary manifestations of COVID-19. Nat Med 26, 1017-1032 (2020).

8. Chen Y, Liu Q, Guo D. Emerging coronaviruses: genome structure, replication, and pathogenesis. J Med Virol. 2020; 92(4): 418-23.

9. European Medicine Agency [EMA]. COVID-19 latest updates. 12 January 2021. https://www.ema. europa.eu/en/human-regulatory/overview/public-health-threats/coronavirus-disease-covid-19/ treatments-vaccines-covid-19 (Date accessed: 13 January 2021).

10. RECOVERY Collaborative Group, Horby $P$, Mafham M, et al.; Effect of Hydroxychloroquine in Hospitalized Patients with Covid-19. N Engl J Med. 2020 Nov 19; 383(21): 2030-2040.

11. RECOVERY Collaborative Group. Lopinavir-ritonavir in patients admitted to hospital with
COVID-19 (RECOVERY): a randomised, controlled, open-label, platform trial. Lancet. 2020 Oct 5; 396(10259): 1345-52.

12. RECOVERY Collaborative Group, Horby P, Lim WS et al; Dexamethasone in Hospitalized Patients with Covid-19 - Preliminary Report. N Engl J Med. 2020 Jul 17: NEJMoa2021436.

13. Peter W Horby, Mark Campbell et al; Tocilizumab in patients admitted to hospital with COVID-19 (RECOVERY): preliminary results of a randomised, controlled, open-label, platform trial, medRxiv 2021.02.11.21249258

14. WHO Solidarity Trial Consortium, Pan H, et al. Repurposed Antiviral Drugs for Covid-19 - Interim WHO Solidarity Trial Results. N Engl J Med. 2020 Dec 2: NEJMoa2023184.

15. Ader F; Discovery French Trial Management Team. Protocol for the DisCoVeRy trial: multicentre, adaptive, randomised trial of the safety and efficacy of treatments for COVID-19 in hospitalised adults. BMJ Open. 2020; 10(9): e041437. Published 2020 Sep 21.

16. Halimi, V., Daci, A., Ridova, N. et al. The use of remdesivir outside of clinical trials during the COVID-19 pandemic. $J$ of Pharm Policy and Pract 13, 61 (2020).

17. Halimi V, Daci A, Stojanovska S, Panovska-Stavridis I, Stevanovic M, Filipce V, Grozdanova A. Current regulatory approaches for accessing potential COVID-19 therapies. J Pharm Policy Pract. 2020 May 16;13:16.

18. Kaur, H., Shekhar, N., Sharma, S. et al. Ivermectin as a potential drug for treatment of COVID-19: an in-sync review with clinical and computational attributes. Pharmacol. Rep (2021).

19. Warren TK, Jordan R, Lo MK, et al. Therapeutic efficacy of the small molecule GS-5734 against Ebola virus in rhesus monkeys. Nature. 2016: Mar 17;531(7594): 381-5.

20. Mulangu S, Dodd LE, Davey RT, Jr, et al. A Randomized, Controlled Trial of Ebola Virus Disease Therapeutics. The New England journal of medicine. 2019; Dec 12; 381(24): 2293-2303.

21. Sheahan TP, Sims AC, Graham RL, et al. Broad-spectrum antiviral GS-5734 inhibits both epidemic and zoonotic coronaviruses. Sci Transl Med. 2017. Jun 28; 9 (396): eaal3653.

22. Sheahan TP, Sims AC, Leist SR, et al. Comparative therapeutic efficacy of remdesivir and combination lopinavir, ritonavir, and interferon beta against MERS-CoV. Nature communications. 2020 Jan 10; 11(1): 222.

23. Wang M, Cao R, Zhang L, et al. Remdesivir and chloroquine effectively inhibit the recently emerged novel coronavirus (2019-nCoV) in vitro. Cell research. 2020 Mar; 30(3): 269-271.

24. S.A. Kujawski, K.K. Wong, J.P. Collins, et al. First 12 patients with coronavirus disease 2019 
(COVID-19) in the United States. medRxiv (2020)

25. J. Grein, N. Ohmagari, D. Shin, et al. Compassionate use of remdesivir for patients with severe COVID-19. N Engl J Med. 2020 Jun 11; 382: 2327-36.

26. Wang Y, Zhang D, Du G, et al. Remdesivir in adults with severe COVID-19: a randomised, double-blind, placebo-controlled, multicentre trial. Lancet. 2020; 395 (10236): 1569-78.

27. Beigel JH, Tomashek KM,et.al; ACTT-1 Study Group Members. Remdesivir for the Treatment of Covid-19 - Final Report. N Engl J Med. 2020 Nov 5; 383(19): 1813-1826.

28. Spinner CD, Gottlieb RL, et.al; Effect of Remdesivir vs Standard Care on Clinical Status at 11 Days in Patients With Moderate COVID-19: A Randomized Clinical Trial. JAMA. 2020 Sep 15; 324(11): 1048-1057.

29. Goldman JD, Lye DCB, et.al; Remdesivir for 5 or 10 Days in Patients with Severe Covid-19. N Engl J Med. 2020 Nov 5; 383(19): 1827-1837.

30. Food and Drug Administration [FDA]. Coronavirus (COVID-19) Update: FDA Approves First Treatment For COVID-19. 22 October 2020. https://www.fda.gov/news-events/press-announcements/fda-approves-first-treatmentcovid-19 (Date accessed 30 November 2020).

31. World Health Organization [WHO] WHO recommends against the use of remdesivir in COVID-19 patients. https://www.who.int/newsroom/feature-stories/detail/who-recommendsagainst-the-use-of-remdesivir-in-covid-19-patients (Date accessed 30 November 2020).

32. National Institutes for Health [NIH]. NIH clinical trial testing antiviral remdesivir plus anti-inflammatory drug baricitinib for COVID-19 begins. 08 May 2020. https://www.nih.gov/news-events/ news-releases/nih-clinical-trial-testing-antiviral-remdesivir-plus-anti-inflammatory-drug-baricitinib-covid-19-begins (Date acessed: 28 November 2020).

33. Gao J, Tian Z, Yang X. Breakthrough: Chloroquine phosphate has shown apparent efficacy in treatment of COVID-19 associated pneumonia in clinical studies. Bioscience trends. 2020 Mar 16; 14(1): 72-73.

34. Biot C, Daher W, Chavain N, et al. Design and synthesis of hydroxyferroquine derivatives with antimalarial and antiviral activities. Journal of medicinal chemistry. 2006; 49(9): 2845-2849.

35. Yao X, Ye F, Zhang M, et al. In Vitro Antiviral Activity and Projection of Optimized Dosing Design of Hydroxychloroquine for the Treatment of Severe Acute Respiratory Syndrome Coronavirus 2 (SARS-CoV-2). Clinical infectious diseases : an official publication of the Infectious Dis- eases Society of America. 2020 Jul 28; 71(15): 732-739.

36. P. Gautret, J.C. Lagier, P. Parola, et al. Hydroxychloroquine and azithromycin as a treatment of COVID-19: results of an open-label non-randomized clinical trial [published online ahead of print] Int J Antimicrob Agents. 2020 Jul; 56(1); 105949.

37. Rosenke K, Jarvis MA, Feldmann F, et al. Hydroxychloroquine proves ineffective in hamsters and macaques infected with SARS-CoV 2. June 11, 2020 (https://www.biorxiv.org/content/10.11 01/2020.06.10.145144v1). Preprint.

38. Skipper CP, Pastick KA, et.al; Hydroxychloroquine in Nonhospitalized Adults With Early COVID-19 : A Randomized Trial. Ann Intern Med. 2020 Oct 20; 173(8): 623-631.

39. Mitjà $\mathrm{O}$, Corbacho-Monné $\mathrm{M}$, et al.; BCN PEPCoV-2 RESEARCH GROUP. Hydroxychloroquine for Early Treatment of Adults with Mild Covid-19: A Randomized-Controlled Trial. Clin Infect Dis. 2020 Jul 16:ciaa1009.

40. Ratia K, Pegan S, Takayama J, et al. A noncovalent class of papain-like protease/deubiquitinase inhibitors blocks SARS virus replication. Proceedings of the National Academy of Sciences of the United States of America. 2008; 105(42): 16119-24.

41. Chan KS, Lai ST, Chu CM, et al. Treatment of severe acute respiratory syndrome with lopinavir/ritonavir: a multicentre retrospective matched cohort study. Hong Kong Med J. 2003; 9(6): 399-406.

42. Cao B, Wang Y, Wen D, Liu W, Wang J, Fan G, et al. A Trial of Lopinavir-Ritonavir in Adults Hospitalized with Severe Covid-19. N Engl J Med 2020 May 7; 382(19): 1787-1799.

43. Joshi S, Parkar J et al. Role of favipiravir in the treatment of COVID-19, International Journal of Infectious Diseases, 2021 Jan; 102: 501-508.

44. Ruan Q, Yang K, Wang W,et al. Clinical predictors of mortality due to COVID-19 based on an analysis of data of 150 patients from Wuhan, China. Intensive Care Med 2020 May; 46(5): 846-848.

45. Chen RC, Tang XP, Tan SY, et al. Treatment of severe acute respiratory syndrome with glucosteroids: the Guangzhou experience. Chest. 2006; 129(6): 1441-1452.

46. Lee N, Allen Chan KC, Hui DS, et al. Effects of early corticosteroid treatment on plasma SARS-associated Coronavirus RNA concentrations in adult patients. Journal of clinical virology : the official publication of the Pan American Society for Clinical Virology. 2004; 31(4): 304-309.

47. Arabi YM, Mandourah Y, Al-Hameed F, et al. Corticosteroid Therapy for Critically Ill Patients 
with Middle East Respiratory Syndrome. American journal of respiratory and critical care medicine. 2018 ; 197(6): 757-767.

48. Shang $\mathrm{L}$, Zhao J, Hu Y, et al. On the use of corticosteroids for 2019-nCoV pneumonia. Lancet. 2020; 395(10225): 683-4.

49. Edalatifard $M$, Akhtari $M$ et al; Intravenous methylprednisolone pulse as a treatment for hospitalised severe COVID-19 patients: results from a randomised controlled clinical trial. Eur Respir J. 2020 Sep 17:2002808.

50. Somers EC, Eschenauer GA, Troost JP, et al. Tocilizumab for treatment of mechanically ventilated patients with COVID-19. Clinical Infectious Diseases. 2020 Jul 11; ciaa954

51. Rossotti R, Travi G, Ughi et al, et al. Safety and efficacy of anti-IL6-receptor tocilizumab use in severe and critical patients affected by coronavirus disease 2019: a comparative analysis. J Infect 2020 Oct; 81(4): e11-e17

52. Guaraldi G, Meschiari M, Cozzi-Lepri A, et al. Tocilizumab in patients with severe COVID-19: a retrospective cohort study. Lancet Rheumatol. 2020 Aug; 2(8): e474-e484

53. Ivan Rosas, Norbert Bräu et al; Tocilizumab in Hospitalized Patients With COVID-19 Pneumonia, medRxiv 2020.08.27.20183442.

54. Stone JH, Frigault MJ, et al; Tocilizumab Trial Investigators. Efficacy of Tocilizumab in Patients Hospitalized with Covid-19. N Engl J Med. 2020 Dec 10; 383(24): 2333-2344.
55. Chen L, Xiong J, Bao L, et al. Convalescent plasma as a potential therapy for COVID-19. Lancet Infect Dis. 2020 Apr; 20(4): 398-400.

56. Li L, Zhang W, Hu Y, et al. Effect of convalescent plasma therapy on time to clinical improvement in patients with severe and life-threatening COVID-19: a randomized clinical trial. JAMA 2020; 324: 460-470.

57. Gharbharan A, Jordans CCE, Geurts van KesselC, et al. Convalescent plasma for COVID-19: a randomized clinical trial. July 3, 2020 (medrxiv 2020.07.01.20139857v1)

58. Agarwal A, Mukherjee A, Kumar G, et al. Convalescent plasma in the management of moderate covid-19 in adults in India: open-label phase II multicentre randomised controlled trial (PLACID Trial). BMJ 2020; 371: m3939-m3939.

59. Simonovich VA, Burgos Pratx LD, et al; PlasmAr Study Group. A Randomized Trial of Convalescent Plasma in Covid-19 Severe Pneumonia. N Engl J Med. 2020 Nov 24.

60. Weinreich DM et al; REGN-COV2, a Neutralizing Antibody Cocktail, in Outpatients with Covid-19. N Engl J Med. 2021 Jan 21; 384(3): 238-251.

61. Chen P, Nirula A, Heller B, Gottlieb RL, Boscia J, Morris J, et al. (January 2021). "SARS-CoV-2 Neutralizing Antibody LY-CoV555 in Outpatients with Covid-19". The New England Journal of Medicine. 384 (3): 229-237. 


\title{
Резиме
}

ПРЕГЛЕД НА АКТУЕЛНИОТ ПРОГРЕС НА НАЈГОЛЕМИТЕ КЛИНИЧКИ ИСПИТУВАЊА ЗА МЕДИКАМЕНТОЗНИОТ ТРЕТМАН НА СОVID-19 ( ДО ЈАНУАРИ 2021)

\author{
Ирина Пановска-Ставридис ${ }^{1}$, Невенка Ридова ${ }^{1}$, Татјана Стојаноска $^{2}$, Илир Демири ${ }^{2}$, \\ Милена Стевановиќ ${ }^{2}$, Симона Стојановска ${ }^{1}$, Тара Ристевска ${ }^{1}$, Александар Димковски ${ }^{3}$, \\ Венко Филипче 4 , Александар Димовски ${ }^{3,5}$, Александра Грозданова $^{3}$ \\ ${ }^{1}$ Универзитетска клиника за хематологија, Медицински факултет, Универзитет „Св. Кирил и \\ Методиј“", Скопје, РС Македонија \\ 2 Универзитетска клиника за инфективни болести и фербилни состојби, Медицински факултет, \\ Универзитет „Св. Кирил и Методиј“, Скопје, РС Македонија \\ ${ }^{3}$ Фармацевтски факултет, Универзитет „Св. Кирил и Методиј“, Скопје, РС Македонија \\ ${ }^{4}$ Универзитетска клиника за неврохирургија, Медицински факултет, Универзитет „Св. Кирил и \\ Методиј“, Скопје, РС Македонија \\ ${ }^{5}$ Истражувачки центар за генетско инженерство и биотехнологија „Георги Д. Ефремов“, \\ Македонска академија на науките и уметностите, Скопје, РС Македонија
}

Пандемијата предизвикана од КОВИД-19 ја генерираше најголемата глобална здравствена криза на 21 век, и доведе и до социоекономски потреси. Покрај брзото и обемно континуирано надополнување на научните сознанија за епидемиологијата, дијагнозата, превенцијата и третманот на КОВИД-19, вирусот SARS-CoV-2 продолжува да се шири во недостиг на дефинитивни и специфични терапевтски агенси. Актуелните тераписки стратегии главно се насочени на вирусна инхибиција со антивирусни лекови и на потиснување на силно поттикнатиот имун одговор на домаќинот со имуномодулаторни лекови. Во овој преглед ги проучуваме податоците од најголемите планирани клинички студии за третманите на COVID-19 објавени во првата година од почетокот на пандемијата. Генерално, овие резултати се однесуваат најмногу на седум лекови: ремдесивир, хлорокин/хидроксихлорокин, комбинацијата од лопинавир-ритонавир, кортикостероиди, тоцилизумаб, конвалесцентна плазма и моноклонални антитела. Во согласност со објавените податоци до јануари 2021 г., најмногу докази ја поддржуваат примената на ремдесивир кај хоспитализирани пациенти со умерена или тешка форма на болеста и обезбедуваат веродостојни податоци за силниот позитивен ефект на кортикостероидите кај хоспитализирани пациенти што имаат потреба од кислородна поддршка. Дополнително, првичните резултати од студијата RECOVERY ја покажаа ефикасноста на тоцилизумаб во третманот на критично болните пациенти. Сѐ уште со ентузијазам ги исчекуваме резултатите за другите имунобазирани тераписки модалитети во третманот на COVID-19.

Клучни зборови: SARS-CoV-2, COVID-19 пандемија, антивирусни лекови, имуномодулаторни лекови, ремдесивир 